\title{
What is after-school childhood like? Children's descriptions of their daily rhythms
}

Kyrönlampi, Taina $\bowtie$

University of Oulu, Finland (Taina.Kyronlampi@oulu.fi)

Määttä, Kaarina

University of Lapland, Finland (Kaarina.Maatta@ulapland.fi)

Uusiautti, Satu

University of Lapland, Finland (satu@uusiautti.fi)

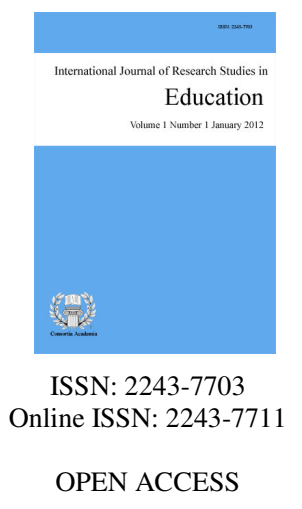

\section{Abstract}

What is good after-school childhood like? How do children perceive their daily rhythm? This study answers the following questions: 1) How are children's daily rhythms structured according to children's descriptions? 2) How do children's autonomy and participation manifest themselves in children's daily rhythms? and 3) How do children describe their encounters with others during their daily rhythm? This study applied phenomenological approach. 12 Finnish third-graders participated in this research. The data were collected in the form of photos that children took themselves and the researcher's discussions with children. The role of after-school time was discussed as a part of children's daily rhythm. The study showed that after-school childhood can be viewed from many points of view. Being alone after the school day can increase children's autonomy and represent time when children can act freely and voluntarily. However, it does not make the time spent together with parents any less important.

Keywords: after school care; children; daily rhythm; phenomenological study; children's experiences 


\section{What is after-school childhood like? Children's descriptions of their daily rhythms}

\section{Introduction}

The way Finnish elementary school pupils spend their afternoons after a school day has been under vivid discussion since the mid-1990s until today (Strandell, 2012). The Finnish Basic Education Act (1998/628) says that municipalities have to arrange morning and afternoon care for the first- and second-graders and to others as widely as the municipality finds reasonable. This means that when children move from the second grade to the third, the municipality is not responsible for arranging morning and afternoon care if the child does not need special care (see Määttä \& Uusiautti, 2012). Children's daily rhythm change when they move from the second grade to the third one because at the time school starts or ends, they do not go to any arranged care but usually go home. In the public discussion, afternoons are defined "lonely" and children's homes "empty", and therefore they are considered unsuitable places for children to spend time while waiting for parents to come home from work (Marshall et al., 1997; Strandell, 2012).

This research addressed the issue of "lonely afternoons" and "empty homes" from a new and unique perspective; namely, by highlighting how children themselves perceive their daily rhythms. The study is to respond to the fact that politics, media, and scientific discussion have not paid particularly much attention to children's experiences of the construction of their everyday life after school days (Belle, 1997; Lowe Vandell \& Shumow, 1999). Parents of the children who participated in this study in a northern-Finnish municipality were worried about the morning and afternoon care arrangements. They concern was focused on how their children will handle afternoons after school alone. They took a stand and wrote in the papers opinions on afternoon care, and the municipalities' responsibilities. According to Strandell and Forsberg (2005), this societal debate reveals how pupils' lonely afternoons form a disputable field of politics and administration in which the idea of "good after-school childhood" is defined.

Basically, there are many options to how to handle after-school care. Lowe Vandell and Shumow (1999) listed at least the following possibilities that parents might choose: (1) formal after-school programs that their children enjoy attending, (2) shifting work schedules, hiring sitters, and setting up activities such as piano lessons and scouts on different days, (3) relatives or neighbors supervising the children after school, and (4) children caring for themselves. In comparison, in the United States, according to Laughlin's (2013) study, in 1997, the proportion of grade school-aged children in self-care was 22 percent, dropping to 19 percent in 1999 , and by spring 2011, being 14 percent (which equals to app. 4.5 million children in self-care).

The purpose of this study is to find out how children's everyday rhythm is like when they do not attend morning or afternoon care. Is it really so that children's afternoons are lonely, unprotected, and desolate? What do children think about that and how do they define "good afternoon childhood"?

\section{Theoretical Background: Viewpoints to Children's Everyday Life, Place, and Empowerment}

The institutionalized school system is a part of the Finnish society. Schools and day care centers are places where children are pigeonholed to wait for becoming adults-childhood is a waiting room of adulthood (Edwards, 1996; Puttonen, 1998). Childhood is often defined as "human becoming" whereas adults are "human being". Such preliminary concepts such as self-knowledge, self-regulation, capability, and developed reasoning and action are associated with adulthood, and children with lack of the aforementioned features. These restricted views have also limited methods and purposes of child research (Uusiautti \& Määttä, 2013). During the past two decades, research has started to consider children socially more "being" than just "becoming" (Alanen, 2009; Allison \& James, 2012; McNamee \& Seymor 2012; Qvortrup, 1994).

Children's rights have been acknowledged in the UN Convention on the Rights of the Child (Unicef, 2008). 
On the one hand, children are perceived as autonomous individuals, on the other hand as people needing protection. Today, children are regarded as active citizens, and playing is in the core of their world. Children's everyday lives are however directed by adults' economic, political, and social decisions. Therefore, children's living conditions are affected by the conditions of adults' everyday life (Jans, 2013).

This study is a part of multidisciplinary and wide field of child research. The $21^{\text {st }}$-century's research has started to emphasize children's agency, participation, and empowerment, and having children as research participants (Karlsson, 2012). Although in scientific research in educational, behavioral, social, and cultural sciences children's perceptions and experiences are increasingly becoming targets of interest, children's experiences of everyday life have been relatively less studied (e.g., Hood et al., 1996; Kyrönlampi \& Määttä, 2013; O’Kane, 2001; Samuelsson, 2004).

The fundamental framework for this study comes from the postmodern conception of childhood. We emphasize children's subjectivity and special position, individuality and active membership in families and communities (e.g., Barker \& Weller, 2003). Children's participation is considered a way of developing together with people educating and upbringing them. This viewpoint differs from the earlier ones according to which children construct information and their experiences "alone" (Christensen et al., 2000). Children develop in the present time and are not just developing and becoming adults (Kronqvist \& Kumpulainen, 2011).

This framework provides the starting point to the methodology and viewpoint of this research. Children's opinions, perceptions, and experiences are approached with ways that enable their active participation, action, decision-making, and voices in the research. How do they perceive their everyday lives?

\section{Method}

\subsection{Research Questions}

The following research questions were set for this study:

1. How are children's daily rhythms structured according to children's descriptions?

2. How do children's autonomy and participation manifest themselves in children's daily rhythms?

3. How do children describe their encounters with others during their daily rhythm?

As the conclusion, the role of afternoon will be discussed as a part of children's daily rhythm.

\subsection{Phenomenological Approach}

This study represents qualitative research paradigm; and applied the phenomenological approach developed by Amadeo Giorgi (1994). The initial idea in this approach is to understand the target phenomenon through research in a way that the outsider-researcher's interpretations are excluded. Experiences are analyzed ontologically by reduction (Giorgi, 1994). This means that in order to be able to see the real phenomenon, the researcher has to get free from preconceptions of, knowledge about and attitudes to the research theme (Giorgi, 1994; Perttula, 2005; van Manen, 1990). Therefore, phenomenology is a suitable approach when researching experiences. The purpose of this study is not to find generalizable findings of Finnish children's everyday lives, although many children in this research would have similar experiences. These similarities are considered as experiential condensations and they are further introduced and discussed in the results section (Perttula, 2005; Rauhala, 2005a, 2005b).

The phenomenological approach aims at understanding the other's experiences and bringing out his or her voice. Research is constructed within interaction between the researcher and the research participants. The researcher has to be able to look at the research phenomenon from a distance, to detach from the predetermined 
reality. This is crucial for finding suitable data collection methods and analyzing methods. Husserl (1995) demands, that the researcher has to disengage himself or herself from the research and its theoretical framework; and to return the practical life time after time, and to see the phenomenon without preconceptions. It means that no hypotheses of the phenomenon can be made but they have to be consciously avoided. Description of the phenomenon can be a way of approaching it open-mindedly - although it is also necessary to admit that a researcher probably cannot totally push aside his or her preconceptions.

In all, in phenomenological research, the researcher and the research participant has vitally different stances in the research (Giorgi, 1994). Reduction is a central method that helps the researcher recognize and reflect his or her own preconceptions about the experiential world (Giorgi, 1994; Perttula, 2005).

When it comes to children's experiential worlds, it seems that the best possible way of analyzing the data might not be categorizing that would be determined solely and strictly by an adult. This can be explained with Perttula's (2005) thoughts who remind that the reality involves plenty of issues that children do not have experience of or clue about because they do not make a part of children's everyday life. Therefore, if an adult decides beforehand how data about children's experiences will be analyzed and categorized, something from children's world can be left unseen. And that something might be quite important for the research participants, the children. There is the danger that an adult is too eager to define beforehand children's experiences, select situations or events for children that the adult himself or herself finds interesting. Thus, the child's everyday life, the child's world remains unreached with all its richness.

Children as research targets therefore challenge the researcher to develop, apply, and study research methods that make it possible for children of various ages to talk about their everyday life. The core challenge is to create the framework for telling and reflect on how to use the information received from children (see Karlsson, 2012; McNamee \& Seymor, 2012).

\subsection{Participants Selection and Permissions}

12 children participated in this research. They all were third-graders living in a sparsely-populated area in northern Ostrobothnia, Finland. The village in which the school was located is small and has one little grocery store. The teacher of the classroom expressed interest in participating in the research, and this was how the selection of the participants proceeded. The class was relatively small with 14 children; of these, parents of two pupils did not give permission to participate in the study.

The rector of the school gave permission for this research. Written permission to use photos and all data was obtained from every parent and child who participated in the research. The researchers have rights to the material and have therefore permission to use the photos taken by the children when reporting the results. In the results section, children are referred to as boys and girls to protect their identities but revealing their gender.

\subsection{The Research Process}

The data were collected in the form of photos and discussions with children. The data collection started with observation days at the school after which children were given mobiles phones with cameras and instructions for photo taking. After this period, the children were interviewed personally. Next, the course of the research is described in detail.

Preparations - The data collection started by asking permissions from parents and children. The classroom teacher distributed the letter for parents. The letter informed about the study and asked for written consent if they allow their children to participate in the research. After having permission from parents, children were asked about their willingness to participate - although it has been criticized why parents should be asked before children (see e.g., Kyrönlampi- Kylmänen, 2007). Two parents did not allow their children to participate, and in practice, this was solved so that when those children who participated were doing research tasks, the others did 
other tasks, such as reading.

Dr. Kyrönlampi familiarized with the children during a few school days. Especially during breaks, she tried to observe children and play and discuss with them. After spending time in the classroom for few days, Dr. Kyrönlampi discussed the research tasks with the classroom teacher. She had composed a task form that introduced topics that children should cover with photos.

\begin{tabular}{|c|c|c|c|c|c|}
\hline TASKS & WEDNESDAY & THUSDAY & FRIDAY & SATURDAY & SUNDAY \\
\hline Morning & & $\begin{array}{l}\text { TAKE THE } \\
\text { CAMERA } \\
\text { PHONE WITH } \\
\text { YOU AT } \\
\text { SCHOOL! }\end{array}$ & & $\begin{array}{l}\text { Take three } \\
\text { pictures of your } \\
\text { doings when } \\
\text { you have woken } \\
\text { up }\end{array}$ & \\
\hline School day & & $\begin{array}{l}\text { Take three } \\
\text { pictures of your } \\
\text { doings during } \\
\text { the break at } \\
\text { school. } \\
\text { Take three } \\
\text { pictures of your } \\
\text { classroom. }\end{array}$ & & & \\
\hline Afternoon & $\begin{array}{l}\text { Take three } \\
\text { pictures of your } \\
\text { doings with } \\
\text { friends. }\end{array}$ & $\begin{array}{l}\text { Take three } \\
\text { pictures of your } \\
\text { way from } \\
\text { school to home. }\end{array}$ & $\begin{array}{l}\text { Take three } \\
\text { pictures of } \\
\text { your doings } \\
\text { during the day. }\end{array}$ & $\begin{array}{l}\text { Take five } \\
\text { pictures of your } \\
\text { doings during } \\
\text { the day. }\end{array}$ & $\begin{array}{l}\text { Take three } \\
\text { pictures of } \\
\text { things that you } \\
\text { find important } \\
\text { to you at home. }\end{array}$ \\
\hline Evening & $\begin{array}{l}\text { Take three } \\
\text { pictures of your } \\
\text { doings at home. }\end{array}$ & & $\begin{array}{l}\text { Take three } \\
\text { pictures of } \\
\text { your doings } \\
\text { with your } \\
\text { family. }\end{array}$ & & $\begin{array}{l}\text { Take two } \\
\text { pictures of } \\
\text { your doings } \\
\text { before } \\
\text { bedtime. }\end{array}$ \\
\hline
\end{tabular}

NAME:

\section{Picture 1. Research tasks form for children}

When planning the research tasks form, the fact that children spend most of their day time at school formed the basis. Finnish third-graders spend at school about 200 days a year, 23 hours a week. The school that participated in this study uses 45-minute-long lessons with 15-minute-long breaks. Lunch time includes a longer break of 45 minutes. In addition, the preliminary thought was that children go to school from home and return home from school. None of the children participating in this research lived for example in a children's home, foster family, or reception center. Therefore, it remains unknown whether children living for example in a children's home would consider it their home to take pictures of. Another group remaining outside this study was children living in turns at their mother's and father's places. The phenomenological method helped to perceive preconceptions and how they influence the planning of research. 
It can be critically reflected on whether the tasks form was necessary. Perttula (2005) argues that the children's experiences do not lose their shine even if the researcher plans the research carefully. Yet, this is something that has to be acknowledged. The number of photographs was limited in order to keep the size of data reasonable.

At the time children received the research tasks form, they also were given personal camera phones. Immediately, buzzing started in the classroom when children started to learn how to use them. They did not need the teacher's or researcher's help, but their relationship with the phones could be described with words playfulness, creativity, and doing together (cf. Kangas, Kultima, \& Ruokamo, 2010). Although some had never used camera phones, they learned it quickly (cf., Punch, 2002). One of the girls concluded that "I learned to use camera and mobile phone better". Children also took the research seriously. At the beginning of an interview, children tend to tell if they had not photographed all necessary themes pointed in the tasks paper: "I missed a couple of photos."

Photos as a way of peeping in the children's world - In this research, photos function as the basis and supplementary data of children's interviews, and as visual descriptors of children's experiences. Photos let the researcher reach emotions, atmospheres, and non-verbal signals that bring closer to the children's experiences. In this study, children discuss the photos and explain what the photos represent. They have photographed their everyday lives, and then asked to describe what they have photographed (see also Kirova \& Emme, 2006).

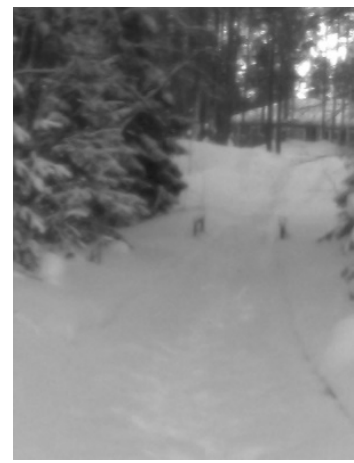

Picture 2. Outside home (A boy)

The expression of photos taken by children (see Setälä, 2012) was deliberately chosen: children do not take pictures about something predetermined but realize the photo and make choices when taking pictures. Often, children's photos are considered random but here we want to emphasize children's activity, choices, and purposes in photographing.

Photographing was chosen as a method also because it does not require reading or writing skills, and therefore it is suitable data collection method even with small children (see Punch, 2002). As children are responsible for taking the pictures, they are more likely to have a confidential relationship with the researcher when considered that the researcher is not involved in the photographing situations. Therefore, photos are firmly connected with the children's everyday reality helping them make their thoughts and feelings more concrete and reachable by research (Barker \& Weller, 2003; Janhonen-Abruquah, 2009; 2012). According to Cele (2006), photos can reach children's experiences, emotions, and mental images better than interviews. Photographing lets children make choices over what they will include in photos (e.g., place, event, situation) or whether they choose to pass the situation. Children's photos reveal what they see in their everyday life: how well we adults really remember what the everyday life was like when we were in the $3^{\text {rd }}$ grade? This type of research has increased during the past decade (Einarsdottir, 2007).

Discussions with children - After having taken the pictures, children were interviewed individually during school days. The photos that children had taken were discussed in the interviews. Children could freely describe the pictures and therefore, the interviews resembled merely discussions or conversations. Each conversation was 
What is after-school childhood like? Children's descriptions of their daily rhythms

recorded and transcript afterwards. The interviews were carried out after the children had taken the photos. The interviews were done at school, after the school day. The interviews lasted for about an hour each.

\subsection{Data Analysis and Ethical Considerations}

The data were analyzed according to Giorgi's (1994) method. The purpose is to bring out what the children's photos reveal without preconceptions of their experiences. The conversations about the photos made this easier because the children's own explanations mattered.

Data collection has aroused the most ethical concern when it comes to childhood research (Strandell, 2010). Research always involves power. In this study, the places that children should photograph were limited (home, school, weekday evenings, weekends) but on the other hand, children could decide which situations and places they wanted to take pictures of. For example, the tasks form could say: "Take three pictures of your doings at home". Einarsdottir (2007) noticed that 2-6-year-old children in her study took pictures of targets they liked and did not remember their actual research task. In this study, the adult's power was used when designing the tasks form, which was reasoned with the fact that the research theme had to be defined carefully. In this sense, the research included collaboration between the researcher and the children.

\subsection{Reliability of the Research}

The phenomenological research approach helps to reflect, critically analyze the data, and question the preliminary assumptions in order to get closer the child's experience. One challenge of child research is that the researcher can act in a contradictory manner and thus fails to reach the child's viewpoint (Karlsson, 2012). The phenomenological approach was employed in this research because it allows to bring out children's experiences as such and as they appear to children themselves without the adult's interpretation.

However, even if a method that is supposed to reach the children's voices is selected, that does not alone guarantee that it actually happens in research. Kyrönlampi and Määttä (2013, p. 54-55) have pointed out how adults know how to produce information about families with children, but not about the children's families; it is not easy to ask in a child-centered way the questions that are meant to decipher what it is like to be a child, what the child's experiences are like, and what the acting in the child's position is like. The combination of various data was used in this study to ensure reliability and chances of reaching the children's world, because when doing research among children, one method might not produce such information the researcher was looking for (Uusiautti \& Määttä, 2013).

In qualitative research like this one, certain points of view regarding to the reliability and validity of the data are worth discussing. Transferability criterion refers to sufficient detail of the context of the fieldwork for a reader to be able to decide whether the prevailing environment is similar to another situation with which he or she is familiar and whether the findings can justifiably be applied to the other setting (Shenton, 2004). We have attempted to meet this criterion by providing a description of the situation in Finland and how afternoon care is usually arranged here compared to some other countries. At the micro level, we also provided sufficient background details about the school and pupils participating in the study.

The meeting of the dependability criterion is difficult in qualitative work in general because the research themes and data are often impossible to repeat (Shenton, 2004). Careful description of the select methods and data obtained are to strengthen the dependability and trustworthiness of the study. Likewise, we have made every effort to demonstrate that a true picture of the phenomenon under research was being presented as it appeared through the data obtained in this research (Shenton, 2004). Although children's photos and interviews could have been influenced to some extent for example by parents, the findings from various data complemented and supported each other. Children as active research partners can be considered rather truthful; already their excitement in photographing places and events important to them gives every reason to believe so. 
Kyrönlampi, T., Määttä, K., \& Uusiautti, S.

Finally, to achieve confirmability, it is important to demonstrate that findings emerge from the data and not from researchers' own predispositions (Shenton, 2004). The select research approach is especially concerned about this issue, and thus, profound reflection at each phase of the research was necessary. Moreover, excerpts from interviews and actual photos were added in the results section to support the researchers' interpretations and to provide the reader a picture of how the themes were discovered from the data. The confirmability of the study can be considered good also because of the combination of research methods.

\section{Results}

\subsection{Third-graders' Daily Rhythm}

Children's school days started by waking up either by themselves or waking by parents. Hurry was present in the morning because they had to make it to school by eight every morning. Children did their morning chores independently: dressed up, brushed teeth and had breakfast. Home was the place they left and returned during weekdays. Children in this study would walk to school alone or with friends. At school, their daily rhythm was determined in the timetable minute by minute. The timetable formed the framework of their days according to which lessons and breaks were into 45-minute and 15-minute periods. Dining, as it lasted for 45 minutes including a break, was the exception. In Fridays, school ended after dining at 11.45 a.m.

Breaks do the rhythm in children's days at school. They were moments during which children could play freely with friends. Girls mostly played with girls and boys with boys. Climbing frame was a place where both girls and boys played tag together frequently. Lunch breaks were also situations making the daily rhythm. Children had quite a natural attitude to food and dining at home and at school. They prepared their breakfast, snacks, and evening meals by themselves. They had one warm course at school.

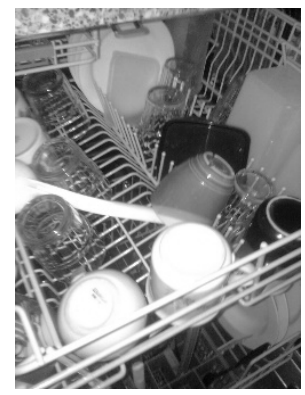

Boy: Here we have bread which is important, and here are dishes that are important. Researcher: What is important with dishes?

Boy: Well, you can drink and eat on them

Picture 3. Dishes

Children did not problematize eating like adults often do. After school, children choose what they would eat, but had surprisingly little say about what they had at home and what was bought from the store. Children returned home from school during winters by walking with friends. Only rarely children's parents took them home. The way to school had certain landmarks, crossroads, trees, paths, and especially the mailbox of one's home. These functioned as signs during the transition from a school child into a home child.

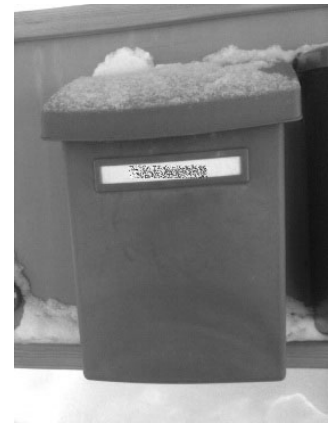

Girl: There is my intermediate stopping point.

Picture 4. Mailbox (A girl) 
Homework given at school became a part of the everyday life at home and made the rhythm after the school days. Homework brought the school worlds at home. Doing homework partly regulated the rhythm at home: most of the children did their homework immediately after coming home after which the rhythm got free and children's own time started.

Home appeared a place of voluntary play, moving, and pottering around. Playing with friends and siblings was important. Home offered opportunities to play inside and outside plays. Boys liked to play with toy cars and Legos, and they played various computer games. Girls seemed to like soft toys, dolls, and self-made toys, such as hobby horses.

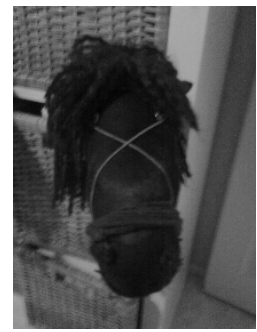

Girl: This is a hobby horse I've made. At the moment, I have four hobby horses. One was bought from a store and others self-made. Now this has Mexican bridle on its head. They are like real horses to me. I go riding outside and inside. Depends on the weather.

Picture 5. A hobby horse (A girl)

As it was winter time, weekday evenings and weekends were spent sliding and building different kinds of huts outside. Girls and boys played together more outside than inside. Mostly children played in their own rooms when being inside. Parents seemed to restrict playing only little at home. Evening chores when well and children were self-directed. Especially girls already planned in the previous evening, what they would wear at school next day. Before going to sleep, children liked to read. Reading seemed pleasant pastime. Especially Donald Duck magazines and books were popular among boys and girls equally. In addition children read fiction books, such as Harry Potter.

The rhythm was slower during weekends than weekdays. Children did not have to wake to alarm, they could play, move around, and be more freely. They also did things together with parents during weekends. Children and parents spent time together by going to trips, visiting relatives, going to sauna and shopping. Girls especially mentioned how much they liked baking.

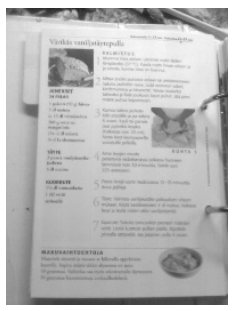

Girl: It was a Saturday evening when I took the picture because our family was baking.

Picture 6. Baking (A girl)

\subsection{Participation and Autonomy}

The hallway at school became a place that could be seen at the borderline of the school institution. The hallway did not have teacher-led and formal order, and it was a transition place that children left and returned. Social culture in hallway was informal. In other words, it was an intersection between the timetable-and curriculum-bound culture and children's free action. School is a typical institutional place in which social culture, especially in classrooms, is formal. The timetable has a prominent and necessary role in the formation of the formal school culture. In addition, every school forms its own social culture and order through its traditions and personnel. Children learn very soon what the social and cultural order of school is (Mayall, 1999).

A child's relationship with school can be analyzed from the point of view of his or her actorship (cf. e.g., James \& Prout, 1990). This viewpoint is closely connected with the research highlighting children's subjectivity. 
Children's ability to solve together flaws of everyday activities is illustrated through action in the hallway. Children had changed the order in the coat track because they had perceived that the previous order had negatively influenced their daily chores, dressing and undressing. They had improved the situations voluntarily without the teacher's guide. Children are active and creative actors who are motivated to improve their amusement and daily life at school (cf., Rautio, 2010; Tuomi-Gröhn, 2008). Children are clever, they notice flaws in the everyday life, and they try actively to correct them without an adult's help.
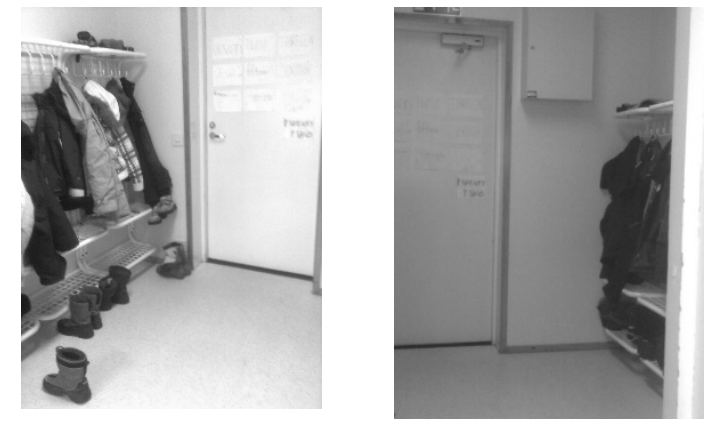

Girl: There is our coat track. Girls have their own side and boys have their own side. Before boys had the larger side although we have fewer boys.

Researcher: Why did you take this photo?

Girl: Well, in the morning, we usually have quite a rush there, and then it calms down later on.

Pictures 7 and 8 . The hallway photographed by a girl (Picture 7) and a boy (Picture 8)

It is important to see how the societal and institutional structures define children's everyday life. In addition, the way people reconstruct and renew these structures through action is crucial. Children produced creative and self-directed solutions to problems at school. Therefore, girls and boys have now split coat racks more reasonably. The rush in the hallway and disorder on coat racks is lesser, which implies that their environment has improved (see Tuomi-Gröhn, 2008).

Christensen et al.'s (2000) study pointed out how children aged 10 to 12 perceived the time after school uncontrolled by adults. Time after school constructed their experiences of autonomy. In this study, children read, watched TV, played computer games, and played either alone or with friends inside or outside after school. It is important to notice that experientally being alone and being lonely are two different things. Being alone is a counterbalance to all rules and conditions at school. Loneliness on the other hand means lack of friends and thus an unwanted situation. Children's being alone turned into being lonely when they would have wanted to play or be with a friend but did not have company for one reason or another. In this study, if a child got bored or felt lonely, he or she invited a friend over, as the following example illustrates:

Girl: In this picture, I do English homework on Friday after school.

Researcher: Does someone check your homework?

Girl: Usually yes. Or we do not have mom or dad at home when I come home from school because they come at some time in the evening. So, my big brother checks because he is really good in English. He usually checks my English homework.

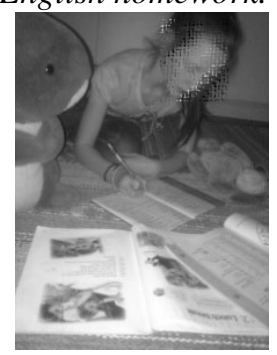

Researcher: Is your big brother at home when you come home?

Girl: Sometimes I have to be alone but sometimes my big brother is at home.

Researcher: How do like being alone at home?

Girl: I does not feel like anything much. Sometimes I call my mom and ask whether I can invite a friend so that I do not have to be alone. A second-grader lives here, who goes to the same school with me, so sometimes I pick her up to our place to play. It is nicer to be with a friend.

Picture 9. Doing homework (A girl)

Children have the innate ability to take pleasure in and enjoy communality and interaction with siblings, parents, relatives, and friends. Siblings, friends, and pets bring comfort when feeling blue. This study showed 
that individuality appeared a more unfamiliar concept to children than it is to adults. The everyday life at school showed how children naturally rejoices of their friends and like to work and study with class mates. This is significant to children and brings pleasure to them. Friends have an important role in learning situations, such as when doing tasks. Whereas adults in work places find their offices peaceful places where they can concentrate and the coffee room is a place for communal action. Based on this study, children seek each other's company. The picture 10 shows how the children's hands are in the picture illustrating friendship.

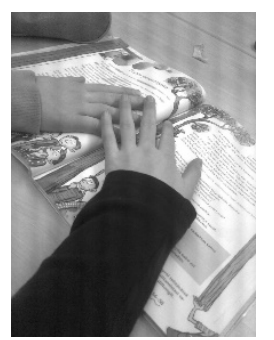

Picture 10. Together (A girl)

Children also used computers while they spent time at home. Adults express often their moral panic when referring to children using computers: what kinds of negative influence the computers have on children's everyday life? However, children can use computers and communications in a way that the adults do not necessarily understand or are not aware of (e.g., Valentine, 2001). In this study, children seemed to use computers naturally both alone and together with other children looking for information they needed. This kind of usage is beneficial to children's cognitive skills and creates opportunities to participate in social and children's collective culture. On the other hand, children are not able to see where the line between moderate and non-moderate use goes. Children do not think in the same way adults do: they do not know that using computers excessively could isolate them from social interaction or cause addiction. They do not know what is beneficial and harmful for their development.

\subsection{Encounter}

Activities during breaks let children act as subjects, which was found experientially significant. Middle-childhood is a phase during which children spend more and more time with friends and form strong friendships. This was shown in this research so that children reported breaks as the most pleasant moments, especially because breaks allow them to play with friends. Children's play includes various levels of action, such as bodilyness, cooperation, creativity, imagination, realizations, and emotions. Plays during breaks activated children's physical activities. Children use their whole bodies when playing, and they also learn social activities through play (Kangas, 2011).

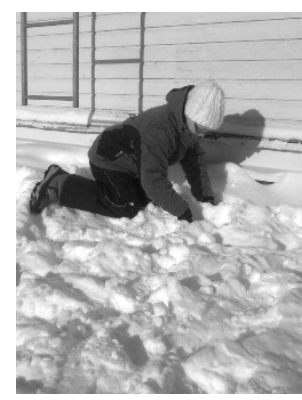

Girl: I am in school yard and dig a hole (laughing)

Researcher: Do you like breaks?

Girl: Yes... because you can play with snow and do stuff.

Picture 11. Playing with snow at school (A girl)

Playing is fun for those involved in the play. Children's voluntary groups, such as groups of friends, try to be out of the adult's sight. Third-graders' peer groups help children to become independent, and dissimilarity and solidarity make an important part of playing. Simultaneously, children's self-image is constructed in relation to 
Kyrönlampi, T., Määttä, K., \& Uusiautti, S.

other children (cf., Vaarala et al., 2013). Likewise, children familiarize with the world of gender roles. Children transmit basic values and information about music, movies, dressing styles, fashion, etc., in their peer groups. It is obvious to belong to a group because it is fun. Children themselves seem to emphasize amusement and fun.

Breaks spent in school yard represented something that provided children relaxation, recreation, and pleasant play. The playing equipment had a salient role in their amusement. Children swung, climbed on the climbing frame, played tag, and frolicked in the snow. Jumping from the swing was obviously intrinsically rewarding, as Picture 12 shows.

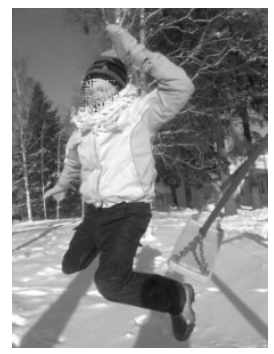

Girl: There we were swinging and jumping from it (laughing). Jenna is jumping from the swing.

Researcher: Do you like swinging?

Girl: Yes.

Picture 12. Jumping from the swing (A girl)

The school yard provided children with opportunities to play various plays and move freely. Girls and boys played tag on the climbing frame: they had made up their own rules that everyone had to follow in order to have the play go well. Children are free during breaks because teachers cannot tell how they should play (see Rantala, 2005).

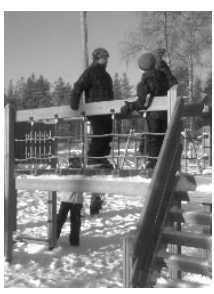

Boy: I almost always play tag on the climbing frame because it is so fun...

Picture 13. The climbing frame (A boy)

In this research, girls and boys played together at school, at grandparents' house, and with siblings at home. Often, a 7-13-year-old child's best friend represents the same gender and these friends spend time and play often at home and at school during breaks.

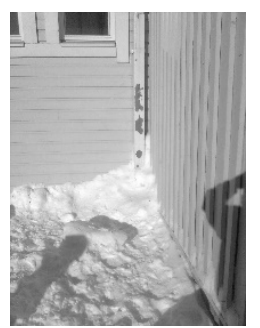

Boy: We played there.

Picture 14. A corner of the school building (A boy)

This research showed that a corner of the school building could serve as a playing place. Children redefined the corner and used places in their environment creatively. This is how the place becomes personally experiential, and children can have subjective meanings, such as emotions, memories, and hopes, regarding certain places (Tuan, 1977). Children found it important that they could discover playing places at school and at home that would be unreachable for adults. They could share their feelings and experiences, and play with other children. 
At home, the kitchen table gathered children to eat, play, and play games. The table was a place for transitions: when moving from daily chores to another.

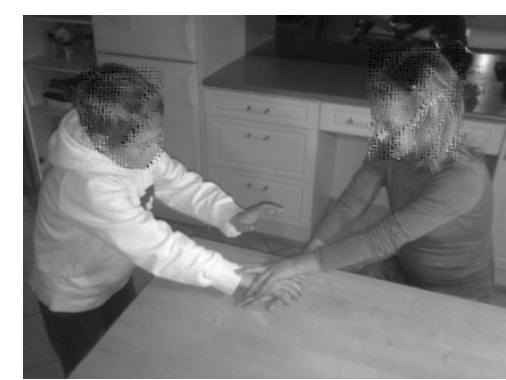

Picture 15. Next to the kitchen table (A boy)

The kitchen table was a natural place for family encounter. Children also read, played, and ate at the table. Moreover, the social ties, love, and caring of the family were expressed by the kitchen table. Family members talked about their doings and experiences when gathering around the table. The dining moment can become a symbolic transition in the middle of hectic weekday rhythm. After dining, family members could continue their own tasks. For children, this means family time. It has been shown that it is crucial for children's well-being that the family gathers at least once a day in the same room (Christensen et al., 2000). Kitchen is the heart of home that has kept its position as the place that puts together the family (Varto, 2001).

This is also important when considering the way children perceive the present and the future. They do not plan their future encounters with their parents like the adults do. Instead, children live here and now, the present moment is meaningful. Therefore, the planning and organization of these moments is the adult's responsibility. Common dining moments are excellent moments and places for parents to stop and listen to how children are doing. Valkonen (2006) noticed that fifth- and six-graders think that good parenthood necessitates that parents care and are interested in their children.

\section{Discussion}

How Does After-School Childhood Manifest Itself According To the Children's Descriptions? - Generally speaking, Finland is a safe place to grow. Therefore, after-school childhood can be viewed from many points of view. Being alone after the school day can increase children's autonomy and represent time when children can act freely and voluntarily (see also Lowe Vandell \& Shumow, 1999). This is experientially significant because it allows children to construct a part of their daily rhythm. Children in this research found it important that they could perform the necessary daily tasks independently according to their developmental level. This finding contradicts for example the current research and attempts developing measures of following children by mobile phones or computers (see e.g., Malone, 2007; Michael, McNamee, \& Michael, 2006). In the light of this study, it was extremely important for children to be able to play and act freely outside the adult's sight.

Home, school, and after-school care that are institutions constructed for children are often viewed opposite to each other, families representing the private and institutions the public sector. Children's social spaces, however, sometimes mold into common, borderless social environment (Strandell, 2012). Homework given from school were tied as a part of the everyday life at home and made a part of the daily rhythm after school. Children in this study brought up that doing things together with parents was important. They did not talk about holiday trips abroad but various encounters during weekdays and weekends. It seemed that parents did not participate in playing but children did daily chores together with parents. 


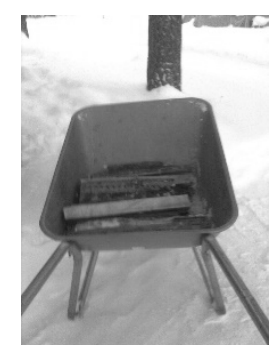

Picture 16. Firewood on a barrow (A boy)

From the point of view of these third-graders, the good after-school childhood would consist of independency, the opportunity to decide by oneself how the afternoon is constructed. The children in this study took care very responsibly of their homework and possible household work. This was how they felt themselves needed, but these tasks also have an educative purpose. Children learn how to bear responsibility and act in a way that they can be trusted. Children seemed to find it experientially significant that they could make decisions over their playing: with whom and what they would play. Playing and friends are important for third-graders. In addition, children found it important the time spent alone is not too long. This depends of children's development too and requires personal attention. Some children can spend longer times alone whereas others can find even short time alone terrifying.

One fundamental factor is safe environment at home and at school. It means that children's basic needs, food, clothing, and way to school, have been taken care of. Safety creates the prerequisites for the development of children's self-direction. If the environment is not safe to a child, the child does not necessarily have the opportunity to enjoy the freedom that is provided to him or her according to his or her age. Indeed, Lowe Vandell and Schumow (1999) remind that afternoon care must be considered in context, in other words, based on the family's perception of the neighborhood where they live.

\subsection{Implications for Practice}

Although we wanted to discuss the role of after-school time in children's everyday lives, it does not make the time spent together with parents any less important (e.g., Sheridan \& Burt, 2009). Therefore, we want to highlight the practical implications that we can draw from the findings. Common doings and daily duties are a natural way of encounter and listen to the children and being present (e.g., Brown \& Ryan, 2003). These situations help them to talk about their joys, worries, and sorrows, and therefore they are important moments for children's well-being (see also Axford, 2009). Likewise, the moments provide parents with a chance to show care, affection, and love (Arendell, 1997; Ebbeck \& Yim, 2009), which should not be forgotten or belittled in the hectic modern life styles. Naturally, families have to create schedules and lifestyles of their own, and the possibility of finding mutual time is not always just a matter of will but influenced by many factors such as parents' work schedules (see e.g., Huhtala, 2012).

A study by Haverinen and Martikainen (2004) showed that the atmosphere of caring created through the interaction between family members is the most important factor for children's well-being. Caring means that the child experiences parents' love which is manifested as practical caring and emotional attachment (see Määttä \& Uusiautti, 2013). Skinnari (2004) has launched the concept of everyday love to illustrate the caring parents manifest in their responsible action. Emotional and social support for children's well-being is meaningful. Home is the seedbed for children's development and usually it remains the most important place until late adolescence (Haverinen \& Martikainen, 2004). The caring atmosphere is also something that is not dependent on the physical assets of the home (cf., Crivello \& Boyden, 2012). Instead, constructive discussions and warmth are universal (Haverinen \& Martikainen, 2004). 
What is after-school childhood like? Children's descriptions of their daily rhythms

The second implication that can be drawn from this study relates to the children's position in everyday lives and their opportunities to act as active subjects. Corsaro (2005) uses the concept "interpretative reproduction". He sees children creative and active members of society; the word "interpretative" refers to this fact. Children create their own peer culture by applying information given by and taken from adults into their peer group activities, such as pretend play and using computers. They do not repeat the old and given information as a matter of routine, but produce culture and society in a new way. When considered from this point of view, projects aiming at limiting children's doing and increasing surveillance by adults are harmful for children's autonomy and take their opportunity to participate in cultural change and renewal. Instead, parents and teachers should provide space for children's autonomous doing, but naturally within the limits suitable to each child's developmental level (Kyratzis, 2004).

This study showed that children's everyday life includes a sort of doing and acting like Pippi Longstocking (a character created by Astrid Lindgren). This means that not only do children need opportunities to develop into autonomous individuals but also their active doing enhances their ability to cope and make their everyday life more amusing. The contribution of this study is that it shows how children themselves perceive their days; the study provides a peep into the children's world. While learning individuality is important, the support and proximity, in the form of time spent with parents, are crucial. Positive experiences in childhood provide resources and strengths that enhance positive development in later life as well (see e.g., Määttä \& Uusiautti, 2011). These unique data presented in this study can help parents and practitioners to decide how to arrange their children's daily rhythm: it opens the curtain to the child's point of view and helps adults to understand how children perceive the days at school, at home and transitions in-between.

Note: Written permission to use photos and all data was obtained from every parent and child who participated in the research. The researchers have rights to the material and have therefore permission to use the photos taken by the children in this article.

\section{References:}

Alanen, L. (2009). Johdatus lapsuudentutkimukseen [Introduction to childhood research]. In L. Alanen \& K. Karila (Eds.), Lapsuus, lapsuuden instituutiot ja lasten toiminta [Childhood, childhood institutions, and children's action] (pp. 9-30). Tampere: Vastapaino.

Allison, J., \& James, A. (2012). Key concepts in childhood studies. Los Angeles, CA: Sage.

Arendell, T. (1997). Contemporary parenting. Challenges and issues. Understanding families. London: Sage.

Axford, N. (2009). Child well-being through different lenses: Why concept matters. Child \& Family Social Work, 14, 372-383. http://dx.doi.org/10.1111/j.1365-2206.2009.00611.x

Barker, J., \& Weller, S. (2003). "Is it fun” developing children centred research methods. International Journal of Sociology and Social Policy, 23(1/2), 33-58. http://dx.doi.org/10.1108/01443330310790435

Belle, D. (1997). Varieties of self-care: a qualitative look at children's experiences in the after-school hours. Merrill-Palmer Quarterly, 43(3), 478-496.

Brown, K. W., \& Ryan, R. M. (2003). The benefits of being present: mindfulness and its role in psychological well-being. Journal of Personality and Social Psychology, 84(4), 822-848. http://dx.doi.org/10.1037/0022-3514.84.4.822

Cele, S. (2006). Communication place. Methods for understanding children`s experience of place. Unpublished doctoral dissertation, University of Stockholm, Stockholm, Sweden.

Christensen, P., James, A., \& Jenks, C. (2000). Home and movement: children constructing "family time". In S. Holloway \& G. Valentine (Eds.), Children`s geographies: playing, living, learning (pp. 139-155).

London: Routledge.

Corsaro, W. (2005). The sociology of childhood. Thousand Oaks, CA: Pine Forge Press.

Crivello, G., \& Boyden, J. (2012). On childhood and risk: an exploration of children's everyday experiences in Rural Peru. Children \& Society. http://dx.doi.org/10.1111/j.1099-0860.2012.00465.x

Ebbeck, M., \& Yim, H. Y. B. (2009). Rethinking attachment: Fostering positive relationships between infants, 
Kyrönlampi, T., Määttä, K., \& Uusiautti, S.

toddlers, and their primary caregivers. Early Child Development and Care, 179(7), 899-909. http://dx.doi.org/10.1080/03004430701567934

Edwards, M. (1996). New approaches to children and development: Introduction and overview. Journal of International Development, 8(6), 813-827. http://dx.doi.org/10.1002/(SICI)1099-1328(199611)8:6<813::AID-JID403>3.0.CO;2-K

Einarsdottir, J. (2007). Research with children: Methodological and ethical challenges. European Early Childhood Education Research Journal, 15, 197-211. http://dx.doi.org/10.1080/13502930701321477

Finnish Basic Education Act. (628/1998). Helsinki: Ministry of Justice. Retrieved from Finlex Database: http://www.finlex.fi/fi/laki/alkup/1998/19980628

Giorgi, A. (1994). A phenomenological perspective on certain qualitative research methods. Journal of Phenomenological Psychology, 25(2), 190-220. http://dx.doi.org/10.1163/156916294X00034

Haverinen, L., \& Martikainen, M. (2004). Rakas lapsi-ei. Kodin kasvattava vuorovaikutus [Dear child - NO. The educative interaction at home]. Helsinki: University of Helsinki.

Hood, S., Kelley, P., \& Mayall, B. (1996). Children as research subjects: a risky enterprise. Children \& Society, 10(2), 117-128. http://dx.doi.org/10.1002/(SICI)1099-0860(199606)10:2<117::AID-CHI17>3.0.CO;2-U

Huhtala, E., Uusiautti, S., \& Määttä, K. (2012). See-sawing between work and home. Shift-working mothers' perceptions on work/family balance. International Journal of Research Studies in Education, 1(2), 31-42. http://dx.doi.org/10.5861/ijrse.2012.v1i2.67

Husserl, E. (1995). Fenomenologian idea: viisi luentoa [The idea of phenomenology: Five lectures]. Helsinki: Lokikirjat.

James, A., \& Prout, A. (1990). Construction and construction and reconstruction childhood: Contemporary issues in the sociological study of childhood. London: Falmer Press.

Janhonen-Abruquah, H. (2009). Valokuvaus kotitaloustutkimuksessa [Photographing in household research]. In H. Janhonen- Abruquah (Ed.), Kodin arki [Everyday life at home] (pp. 173-180). Helsinki: University of Helsinki.

Janhonen-Abruquah, H. (2012) Everyday life of families in global world. In D. Pendergast, S. L. T. McGregor, \& Turkki, K. (Eds.), Creating home economics futures: The next 100 years (pp. 132-142). Bowen Hills: Australian Academic Press.

Jans, M. (2013). Children as citizens: Towards a contemporary notion of child participation. Childhood, 11(1), 27-44. http://dx.doi.org/10.1177/0907568204040182

Kangas, M. (2011). The school of the future. Theoretical and pedagogical approaches for creative and playful learning environments. Unpublished doctoral dissertation, University of Lapland, Rovaniemi, Finland.

Kangas, M., Kultima, A., \& Ruokamo, H. (2006). Co-Creative Learning processes (CCLP) - Children as game world creators to the outdoor playgroud contexts. In J. Multiska \& H. Haaparanta (Eds.), Proceedings of the Workshop on Human Cetred Technology (pp.14-21) Pori: Tampere University of Technology.

Karlsson, L. (2012). Lapsinäkökulmaisen tutkimuksen ja toiminnan poluilla [On the paths of child-centered research and action]. In L. Karlsson \& R. Kerimäki (Eds.), Sukelluksia lapsinäkökulmaiseen tutkimukseen ja toimintaan [Views to child-centered research and action] (pp. 17-66). Jyväskylä: Finnish Educational Research Association.

Kirova, A., \& Emme, M. (2006). Using photography as a means of phenomenological seeing: "Doing phenomenology" with immigrant children. Indo-Pacific Journal of Phenomenology, 8, 1-12.

Kronqvist, E.-L., \& Kumpulainen, K. (2011). Lapsuuden oppimisympäristöt. Eheä polku varhaiskasvatuksesta kouluun [Childhood learning environments. Smooth path from early childhood education to school]. Helsinki: WSOYpro.

Kyratzis, A. (2004). Talk and interaction among children and the co-construction of peer groups and peer culture. Annual Review of Anthropology, 33, 625-649. http://dx.doi.org/10.1146/annurev.anthro.33.070203.144008

Kyrönlampi-Kylmänen, T. (2007). Arki lapsen kokemana. Eksistentiaalis-fenomenologinen haastattelututkimus [Everyday life from the point of view of the child: insights from existential phenomenological 
What is after-school childhood like? Children's descriptions of their daily rhythms

interviews]. (PhD., Diss., University of Lapland, Rovaniemi, Finland.)

Kyrönlampi, T., \& Määttä, K. (2013). Using children as research subjects: How to interview a child aged 5 to 7 years. In S. Uusiautti \& K. Määttä (Eds.), How to study children? Methodological solutions of childhood research (pp.51-66). Rovaniemi: Lapland University Press.

Laughlin, L. (2013). Who's minding the kids? Child care arrangements: Spring 2011. Current Population Reports, P70-135. Washington, DC: U.S. Census Bureau. Retrieved from http://www.census.gov/prod/2013pubs/p70-135.pdf

Lowe Vandell, D., \& Shumow, L. (1999). After-school child care programs. The Future of Children, 9(2), 64-80. http://dx.doi.org/10.2307/1602707

Malone, K. (2007). The bubble-wrap generation: children growing up in walled gardens. Environmental Education Research, 13(4), 513-527. http://dx.doi.org/10.1080/13504620701581612

Marshall, N. L., Garcia Coll, C., Marx, F., McCartney, K., Keefe, N., \& Ruh, J. (1997). After-school time and children's behavioral adjustment. Merrill-Palmer Quarterly, 43(3), 497-514.

McNamee, S., \& Seymor, J. (2012). Towards a sociology of 10-12 year olds? Emerging methodological issues in the "new" social studies of childhood. Childhood, 9, 1-13.

Mayall, B. (1999). Children, health and the social order. Buckingham: Open University Press.

Michael, K., McNamee, A., \& Michael, M. G. (2006). The emerging ethics of humancentric GPS tracking and monitoring. In Proceedings of the International Conference on Mobile Business, Copenhagen, Denmark, 25-27 July 2006. M Business Revisited from Speculation to Reality (pp. 1-15). Piscataway, NJ, USA: IEEE.

Määttä, K. \& Uusiautti, S. (2011). How to enhance the smoothness of university students' study paths? International Journal of Research Studies in Education, 1(1), 47-60.

Määtä, K., \& Uusiautti, S. (2012). How do the Finnish family policy and early education system support the well-being, happiness, and success of families and children? Early Child Development and Care, 182(3-4), 291-298. http://dx.doi.org/10.1080/03004430.2011.646718

Määttä, K., \& Uusiautti, S. (2013). Many faces of love. Boston/Rotterdam/Taipei: Sense Publishers. http://dx.doi.org/10.1007/978-94-6209-206-8

O'Kane, C. (2001). The development of participatory techniques: facilitating children`s views about decisions with affect them. In P. Christenssen \& A. James (Eds.), Research with children. Perspectives and practices (pp. 136.159). London: Routledge Falmer.

Punch, S. (2002). Research with children: the same or different from research with adults? Childhood, 9(3), 321341. http://dx.doi.org/10.1177/0907568202009003005

Perttula, J. (2005). Kokemus ja kokemuksen tutkimus: Fenomenologisen erityistieteen tieteenteoria [Experience and research on experience: The philosophy of science of phenomenological special discipline]. In J. Perttula \& T. Latomaa (Eds.), Kokemuksen tutkimus. Merkitys-Tulkinta-Ymmärtäminen [Research on experience. Meaning-Interpretations-Understanding] (pp. 115-158). Tartu: Dialogia.

Puttonen, M. (1998). Aikuisten varjossa [In the shadow of adults]. Yliopisto-lehti, 3, 6-11.

Rautio, P. (2010). Writing about everyday beauty in northern village. An argument for diversity of habitable tables. (PhD. Diss., University of Oulu, Oulu, Finland.)

Rantala, T. (2005). Oppimisen iloa etsimässä - kokemuksen etnografiaa alkuopetuksessa [Seeking the joy of learning - the ethnography of experience in elementary instruction]. (PhD. Diss., University of Lapland, Rovaniemi, Finland.)

Rauhala, L. (2005a). Tajunnan itsepuolustus [Self-defense of consciousness]. Helsinki: Helsinki University Press.

Rauhala, L. (2005b). Hermeneuttisen tieteenfilosofian analyyseja ja sovelluksia [Analyses and applications of hermeneutic philosophy of science]. Helsinki: Helsinki University Press.

Samuelsson, I. P. (2004). How do children tell us about their childhoods? Early Childhood Research and Practice, 6, 1-15.

Skinnari, S. (2004). Pedagoginen rakkaus. Kasvattaja elämän tarkoituksen ja ihmisen arvostuksen äärellä [Pedagogical love. Educators by the meaning of life and appreciation of human beings]. Jyväskylä: 
Kyrönlampi, T., Määttä, K., \& Uusiautti, S.

PS-kustannus.

Shenton, A. K. (2004). Strategies for ensuring trustworthiness in qualitative research projects. Education for Information, 22, 63-75.

Sheridan, S. M., \& Burt, J. D. (2009). Family-centered positive psychology. In S. J. Lopez \& C. R. Snyder (Eds.), Oxford handbook of positive psychology (pp. 551-559). Oxford: Oxford University Press.

Strandell, H. (2012). Liikkuminen ja yhteydenpito paikan tekemisessä. Leikkipuisto koululaisten iltapäivätoiminnan näyttämönä [Moving and interaction in making of places. Play ground as the scene of school children's after-school activities]. In H. Strandell, L. Haikkola, \& K. Kullman (Eds.), Lapsuuden muuttuvat tilat [Changing spaces of childhood]. Tampere: Vastapaino.

Strandell, H., \& Forsberg, H. (2005). Kohti kurinalaista lapsuutta? Kysymys pienten koululaisten iltapäivien (uudelleen) määrittelystä [Toward disciplined childhood? A question of (re)definition of young school children's afternoons]. Yhteiskuntapolitiikka, 70(6), 610-622.

Setälä, P. (2012). Lapsi kuvan takana: erityisiä piirteitä lasten valokuvailmaisussa [Child behind the picture: Special features in children's photographical expression]. Helsinki: Musta Taide.

Tuan, Y.-F. (1977). Place: an experiential perspective. New York, NY: American Geographical Society.

Tuomi-Gröhn, T. (2009). Kodin arki ja arjen taidot tutkimuskohteena [The everyday life of home and everyday skills as research targets]. In H. Janhonen-Abruquah (Ed.), Kodin arki [Everyday life at home] (pp. 147-156). Helsinki: University of Helsinki.

Unicef. (2008). Convention on the rights of the child. Retrieved from: http://www. unicef.fi

Uusiautti, S., \& Määttä, K. (2013). Many dimensions of child research. In S. Uusiautti \& K. Määttä (Eds.), How to study children? Methodological solutions of childhood research (pp. 11-28). Rovaniemi: Lapland University Press.

Qvortrup, J. (1994). Childhood matters: social theory, practice and politics. Aldershot: Avebury.

Vaarala, M., Uusiautti, S., \& Määttä, K. (2013). College students' experiences of and coping with loneliness possibilities of peer support. International Journal of Research Studies in Education, 2(4), 13-28. http://dx.doi.org/10.5861/ijrse.2013.510

Valkonen, L. (2006). Millainen on hyvä äiti ja isä? Viides- ja kuudesluokkalaisten lasten vanhemmuuskäsityksiä [What is a good mom and dad like? Fifth- and six-graders' perceptions of parenthood]. Jyväskylä: University of Jyväskylä.

Van Manen, M. (1990). Researching lived experience: human science for action sensitive pedagogy. New York, NY: State University of New York Press.

Varto, J. (2001). Kauneuden taito: estetiikkaa taidekasvattajille [The skill of beauty: aesthetics for art educators]. Tampere: Tampere University Press. 